\title{
Disabilities in leprosy: construction and validation of instrument on knowledge and attitude of professionals
}

\author{
Incapacidades na hanseníase: construção e validação de instrumento sobre conhecimento e atitude de profissionais
}

Discapacidades en la lepra: construcción y validación de un instrumento sobre el conocimiento y la actitud de los profesionales.

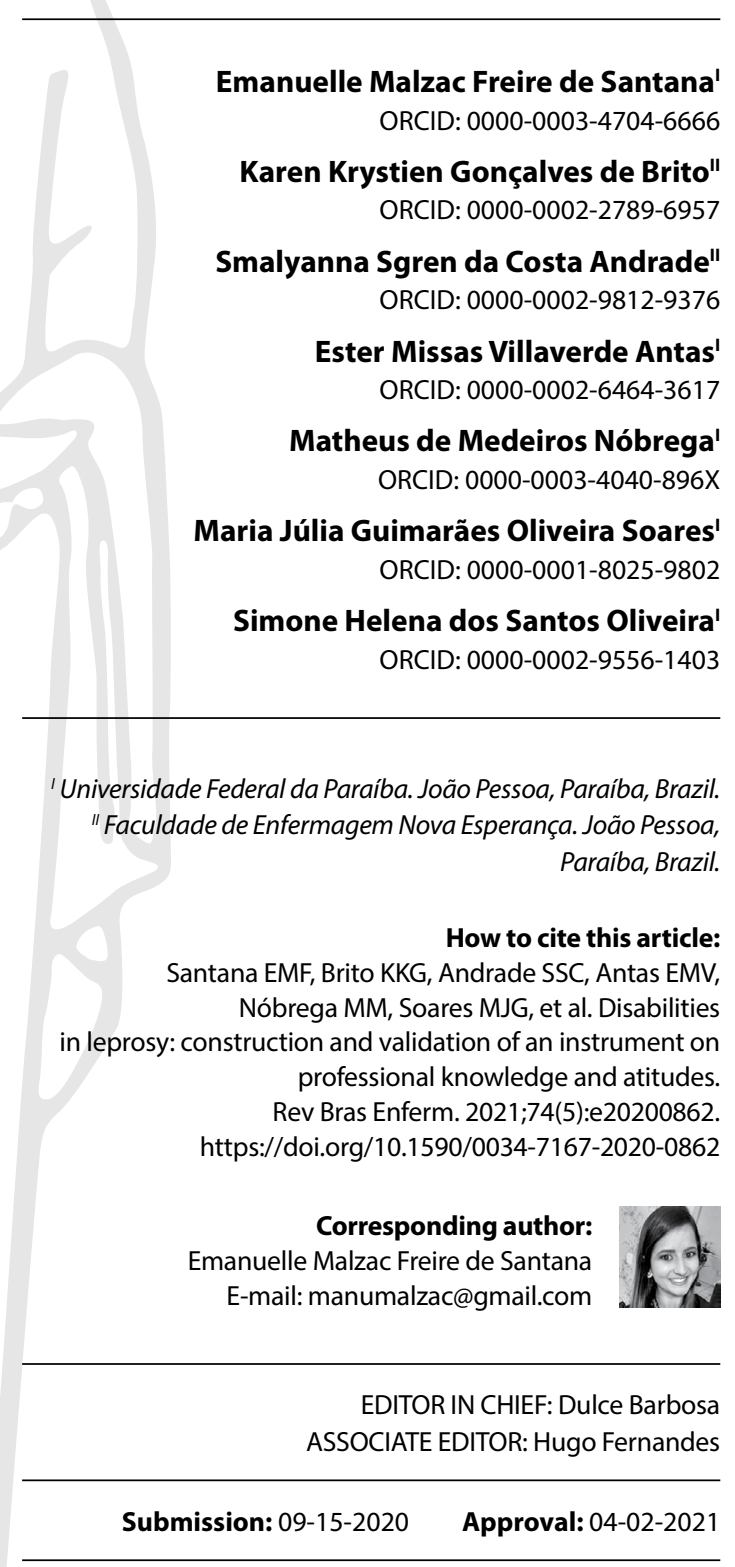

\begin{abstract}
Objective: To develop and test the content validity of the "Knowledge and Attitudes on Assessing Degrees of Physical Disability in Leprosy" instrument. Methods: Methodological study carried out between January and May 2019 in three stages: item generation, analysis of aggregated redundancy to the composition, and content validation, using the Delphi technique. Results: In the first evaluation, a relevance of $\geq 0.80$ stood out for all items, except for 2.8, which was excluded. To make the instrument clearer, the sequence was renumbered from one to $32 ; 2.6,3.1$, and 15 were reformulated, and the others underwent modifications, except for ten and 13. After the second evaluation, all items obtained Content Validity Index $>0.90$ and Kappa $=1.00$. Conclusion: The instrument has an excellent content validity; it is inferred that it is adequate to measure the knowledge and attitudes of professionals in the assessment of physical disabilities in leprosy.

Descriptors: Knowledge; Attitude; Leprosy; Validation Study; Health Education.
\end{abstract}

\section{RESUMO}

Objetivo: Construir e testar a validade de conteúdo do instrumento "Conhecimento e Atitude sobre a Avaliação do Grau de Incapacidade Física na Hanseníase". Métodos: Estudo metodológico realizado entre janeiro e maio de 2019 em três etapas: geração de itens, análise de redundância agregada à composição e validação de conteúdo, utilizando a técnica Delphi. Resultados: Na primeira avaliação, destaca-se relevância $\geq 0,80$ para todos os itens, exceto para 2.8, que foi excluído. Para tornar o instrumento mais claro, a sequência foi renumerada de 1 a 32; 2.6, 3.1 e 15 foram reformulados, e os demais passaram por modificações, exceto 10 e 13. Após a segunda avaliação, todos os itens obtiveram Índice de Validade de Conteúdo $>0,90$ e Kappa $=1,00$. Conclusão: $O$ instrumento possui validade de conteúdo excelente infere-se que é adequado para mensurar os conhecimentos e as atitudes dos profissionais sobre a avaliação das incapacidades físicas na hanseníase.

Descritores: Conhecimento; Atitude; Hanseníase; Estudo de validação; Educação em Saúde.

\section{RESUMEN}

Objetivo: Construir y testar la validez de contenido del instrumento "Conocimiento y Conducta acerca de Evaluación del Grado de Discapacidad Física en la Lepra". Métodos: Estudio metodológico realizado entre enero y mayo de 2019 en tres etapas: generación de ítems, análisis de redundancia agregada a la composición y validez de contenido, utilizando técnica Delphi. Resultados: En la primera evaluación, destacó relevancia $\geq 0,80$ para todos ítems, excepto para 2.8, que fue excluido. Para volver el instrumento más claro, la secuencia fue renumerada de 1 a 32; 2.6, 3.1 y 15 fueron reformulados, y los demás pasaron por modificaciones, excepto 10 y 13 . Después de la segunda evaluación, todos ítems obtuvieron Índice de Validez de Contenido $>0,90$ y Kappa $=1,00$. Conclusión: Instrumento posee validez de contenido excelente; infiere que es adecuado para mensurar los conocimientos y conductas de profesionales acerca de evaluación de las discapacidades físicas en la Lepra. Descriptores: Conocimiento; Conducta; Lepra; Estudio de validación; Educación en Salud. 


\section{INTRODUCTION}

Considered the infectious disease that causes most disabilities in individuals due to its neural involvement capacity ${ }^{(1)}$, leprosy still represents an important public health problem in Brazil. Despite the efforts made to eliminate it, the disease still remains endemic in the country, which annually reports about 26 thousand new cases $^{(2)}$.

Data from the World Health Organization indicates that, between the years 2016 and 2017, there was an increase in the number of new cases $(+1,657)$ and new cases diagnosed with a degree of physical disability (DPD) $2(+213)$, represented by the presence of visible deficiencies caused by leprosy, such as lagophthalmos, trichiasis, ectropion, claws, bone resorption, muscle atrophy, ulcers, among others ${ }^{(2)}$.

For early identification of neural damage and determining the DPD, the Ministry of Health $(\mathrm{MH})$ advises the periodic Simplified Neurological Examination (SNE), an examination that comprises the stages of anamnesis, inspection of body sites (face, upper and lower limbs), peripheral nerves palpation/percussion, manual muscle strength test and sensitivity test ${ }^{(3)}$.

However, despite the frequent publication of manuals, guidelines, and national and international protocols to guide health professionals' conduct regarding disabilities, studies indicate the presence of gaps in the training of Primary Care (PC) professionals in the management of the disease, among them: long and conflicting therapeutic itinerary to identify signs and symptoms ${ }^{(4)}$, unpreparedness to proceed with the evaluation of the DPD ${ }^{(5)}$, and lack of knowledge on the scope of activities related to its prevention and control ${ }^{(6)}$.

These gaps can foster opportunities for the emergence of deficiencies and, therefore, stigmas and prejudices, which limits the performance of activities and restricts the social participation of patients, generating consequences in the economic, social, cultural, and emotional spheres ${ }^{(7)}$.

Understanding that PC should be responsible for the integral care of individuals with leprosy and that the professionals inserted in this context must have adequate knowledge and attitudes in light of the problems that involve the disease, in line with the guidelines proposed by the $\mathrm{MH}$, the construction and validation of an instrument to measure the knowledge and attitudes of these professionals on this issue is justified. This will allow to identify gaps in their knowledge and opinions to assist in the development of educational strategies, aiming to improve the quality of care.

It should be noted that, while searching for the current literary production on the disease, no validated instruments were found addressing the theme of evaluation of DPD in leprosy.

\section{OBJECTIVE}

To develop and test the content validity of the "Knowledge and Attitudes on Assessing Degrees of Physical Disability in Leprosy" instrument.

\section{METHODS}

\section{Ethical aspects}

The study was approved by the Ethics and Research Committee of the Health Sciences Center of the Universidade Federal da Paraíba [Federal University of Paraíba], and the participating professionals signed the Free and Informed Consent Term (FICT), complying with the ethical observations contemplated in Resolution No. 466/12 of the National Health Council.

\section{Study design, period and location}

Methodological study, using a quantitative approach, carried out between the months of January and May 2019, in João Pessoa, state of Paraíba, Brazil, for the construction and validation of the content of the "Knowledge and Attitudes on Assessing Degrees of Physical Disability in Leprosy" instrument, developed to measure the knowledge and attitude of $P C$ professionals on the evaluation of the DPD of leprosy patients.

\section{Study protocol}

The theoretical framework adopted for content validation in this study was the one exemplified by Raymundo(8), which comprises the following steps: item generation, related to the collection of errors for the assembly of the instrument; analysis of redundancy added to the composition, which consists of grouping the errors according to the similarity of the items and development of the instrument; and content validation, to analyze items representativeness by specialists in a given theme.

In the first stage, which corresponds to the generation of items, the literature was looked at for publications that dealt with the evaluation of the DPD of leprosy patients and opting to build the instrument based on the information contained in the SNE form available in the current $\mathrm{MH}$ guidelines on the disease, "Practical guide on leprosy", designed to assist health professionals in its confrontation throughout the Brazilian territory ${ }^{(3)}$.

In the subsequent stage, analysis of redundancy added to the composition, the items of the instrument were formulated with a dichotomous question on the knowledge of the instrument, with the possibility of answering "yes" or "no"; four multiplechoice questions addressing clinical cases and 27 questions with a three-point Likert scale, which allows respondents to express their degree of agreement with a statement, presenting sufficient response options and requiring little response time ${ }^{(9)}$.

The items were grouped into two constructs, "knowledge" and "attitudes", which covered two dimensions, SNE and DPD, totaling 33 questions. The concepts of knowledge and attitudes adopted for the construction of the items were: "remembering specific aspects or the ability to apply specific aspects to solve problems" and "essentially, having opinions", respectively ${ }^{(10)}$.

It is emphasized that, in order to avoid the appearance of the acquiescence effect, that is, a tendency towards affirmative answers in questions with which one does not agree or disagree, it was decided to insert negative items into the instrument ${ }^{(9)}$.

In the third and final stage, pertaining content validation, a body of judges was selected by evaluating their curriculum at the Lattes Platform, of the National Council for Scientific and Technological Development, with 43 curriculums using the "leprosy", "health professionals" and "minimum master's degree" filters, applying the following eligibility criteria: minimum experience of five years in the area and authorship of at least two scientific articles on the subject in the last five years ${ }^{(11)}$. 
Using the Delphi technique ${ }^{(12)}$, delimited by two rounds of evaluation, an e-mail was sent to the judges (first Delphi stage), containing an invitation letter with guidelines to participate in the research, the first version of the instrument "Knowledge and Attitudes on Assessing Degrees of Physical Disability in Leprosy" and the FICT, establishing a 30-day period to return the instrument.

The judges were instructed to analyze the items of the instrument as to relevance (they are important and consistent with the attribute of measuring knowledge and attitudes) and clarity (they are understandable, unambiguous, and with easy expressions, with coherence between the questions), being ordered on a Likert scale: 1 - not relevant/clear; 2 - little relevance/clarity; 3 - relevant/clear; and 4 - very relevant/clear ${ }^{(13)}$. In addition, there was room to suggest modifications/reformulations.

In all, 13 judges signed the FICT and responded to the instrument. Considering that this quantity was higher than that established as ideal by Pasquali ${ }^{(14)}$ to compose a sample of evaluators, that is, between six and ten specialists, the validation process moved forward.

After receiving the instruments, appropriate modifications were made according to judges' orientations, and the second version of the instrument (second Delphi stage) was sent back to the judges, adopting the same evaluation criteria (clarity and relevance), with a deadline of 15 days for reassessment. A total of 11 judges participated in the second evaluation round.

\section{Analysis of results and statistics}

The data were analyzed using the Content Validity Index (CVI), which measured the percentage of judges who agreed on the items of the instrument. The items that were evaluated and received a score of " 1 " or " 2 " were either reviewed or excluded from the instrument, with the calculation of the CVI performed using the sum of the scores " 3 " and " 4 " of each judge in each instrument item, dividing the result by the total number of responses ${ }^{(13)}$. Thus, the items that obtained an agreement level greater than or equal to 0.80 remained, that is, the answers that obtained a frequency equal to or greater than $80 \%$. After the second evaluation round, it was decided to increase the agreement rate as acceptable to 0.90 , with the purpose of increasing reliability, in view of the reduction of the sample ${ }^{(13)}$.

Aiming to measure the intensity of agreement between the judges, the Kappa Index (K) was used, considering less than 0 - no agreement; 0 to 0.19 - poor; 0.20 to 0.39 - reasonable; 0.40 to 0.59 - moderate; 0.60 to 0.79 - substantial; 0.80 to 1.00 - excellent/almost perfect.

\section{RESULTS}

The body of 13 judges was composed predominantly of females (84.6\%), over 50 years of age (69.2\%), experience in the field for more than 20 years $(69.2 \%)$, doctorate degree (76.9\%), and authorship of scientific articles related to the theme (100\%), with nine nurses, two occupational therapists, a physiotherapist, and a doctor.

Regarding the analysis of the items' clarity and relevance, Tables 1 and 2 show the CVI values obtained in the first Delphi evaluation step, with relevance $\geq 0.80$ for all items, except 2.8 , which was excluded. To make the instrument clearer, the item sequence was renumbered from one to 32; items 2.6, 3.1, and 15 were reformulated; and the others underwent modifications, with the exception of items 10 and 13.
Table 1 - Judges' assessment regarding the criteria of clarity and relevance of the questions related to knowledge, according to the content validity index in the first Delphi stage ( $N=13)$, João Pessoa, Paraíba, Brazil, 2019

\begin{tabular}{|c|c|}
\hline Variables & $\begin{array}{l}\text { First Delphi Stage } \\
\text { Clarity Relevance }\end{array}$ \\
\hline Questions pertaining to knowledge & $\mathbf{C V I} \mathbf{l}^{*}$ \\
\hline
\end{tabular}

1. Are you familiar with or have you heard about the 0.69 simplified neurological examination form?

[ ] Yes [ ] No

2. Regarding the simplified neurological evaluation, please check disagree, don't know, or agree on the statements below:

2.1 It is used to assist in diagnosing leprosy.

$0.92 \quad 1$

[ ] Disagree [ ] Don't know [ ] Agree

2.2 It makes it possible to monitor the treatment of neuritis.

[ ] Disagree [ ] Don't know [ ] Agree

2.3 It allows to classify the degree of physical disability of the individual.

[ ] Disagree [ ] Don't know [ ] Agree

2.4 It must be performed in the craniocaudal sequence.

[ ] Disagree [ ]Don't know [ ] Agree

$2.5 \mathrm{It}$ is recommended every two months during treatment if the individual does not report complaints.

[ ] Disagree [ ]Don't know [ ] Agree

2.6 The ballpoint pen can replace the SemmesWeinstein monofilaments in the assessment of sensitivity in hands and feet.

[ ]Disagree [ ]Don't know [ ] Agree

2.7 The eye sensitivity test can be performed without dental floss.

[ ] Disagree [ ]Don't know [ ] Agree

2.8 Anhidrosis can be observed by finding "islets" in dry areas.

[ ] Disagree [ ]Don't know [ ]Agree

2.9 Septum dryness, wound, and perforation are items evaluated in the nose.

[ ]Disagree [ ]Don't know [ ]Agree

2.10 The median, ulnar, radial, tibial, and sciatic nerves should be investigated during the palpation stage.

[ ]Disagree [ ]Don't know [ ]Agree

2.11 The eye closing strength should be verified during eye evaluation.

[ ] Disagree [ ] Don't know [ ] Agree

2.12 Muscle strength can be graded from 0 to 5 , where 0 corresponds to muscle contraction without movement; and 5 , the ability to perform the complete movement against gravity, with resistance. [ ] Disagree [ ] Don't know [ ] Agree

3. Regarding the degree of physical disability, please indicate disagree, don't know, or agree on the statements below:

3.1 Indicates the loss of protective sensitivity and/or visible deformity as a result of neural injury and/or blindness.

[ ] Disagree [ ]Don't know [ ] Agree

3.2 It should be performed only at the time of diagnosis and of discharge due to cure.

[ ] Disagree [ ] Don't know [ ] Agree
$0.84 \quad 1$

0.92 
Table 1

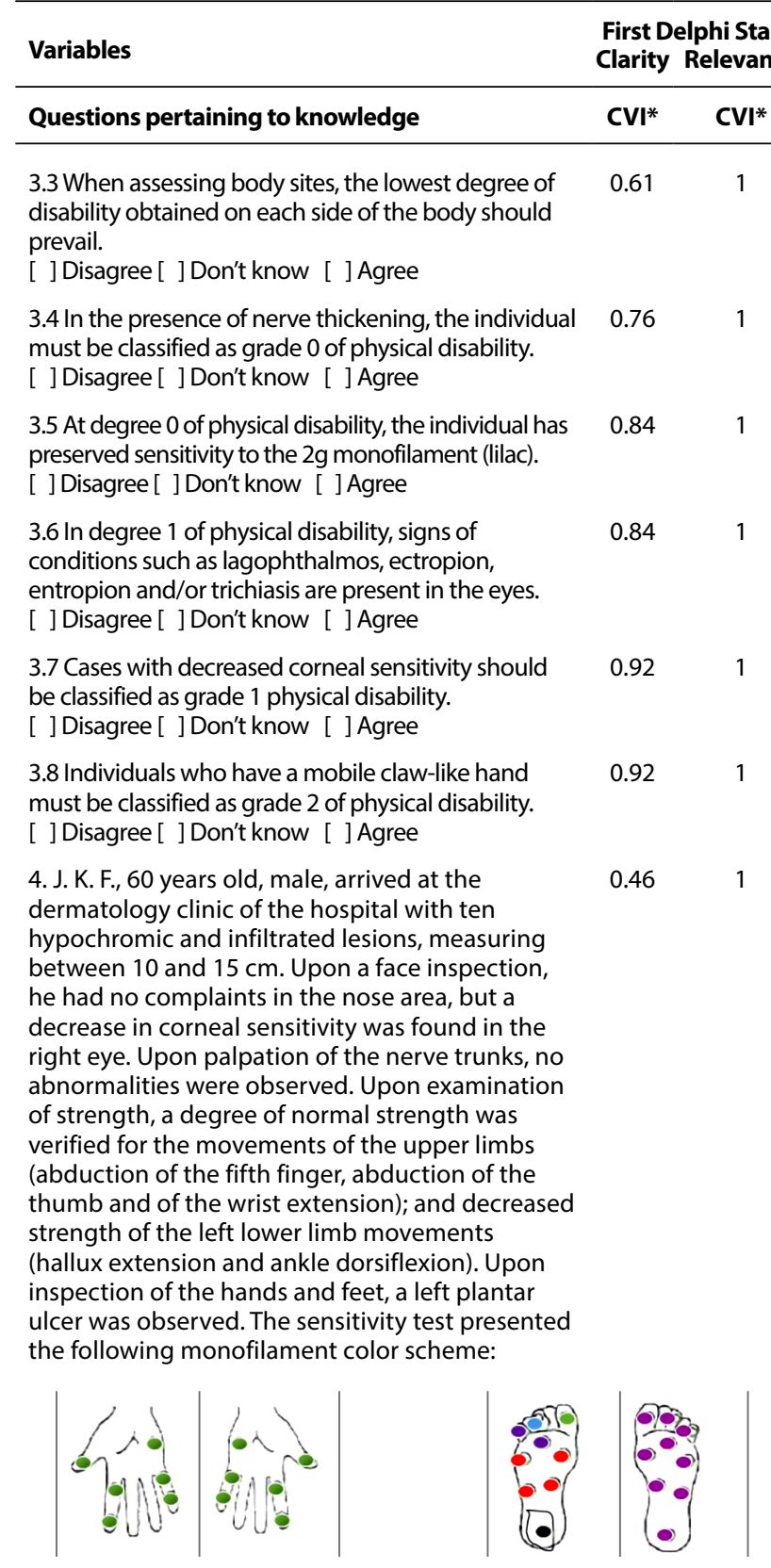

Legenda: Canela/filamento lilás(2g): Sente $\checkmark$ Não senteX ou Monofilamentos: seguir cores Garra móvel: $\mathbf{M}$ Garra rígida: $\mathbf{R}$ Reabsorção:

Based on this information, what is this individual's degree of disability?

[ ] degree 0 [ ] degree 1 [ ] degree 2

5. P. G. R., 20 years old, male, arrived at the hospital dermatology clinic presenting a high and totally anesthetic lesion. While evaluating his face, dryness in the nose and absence of ocular complaints was noted. During palpation of the nerve trunks, it was found that only the median nerve of the right upper limb was thickened and painful. Upon strength examination, a normal degree was found for all movements of the upper and lower limbs (abduction of the fifth finger, abduction of the thumb and wrist extension, hallux extension and ankle dorsiflexion). The sensitivity test presented the following monofilament color scheme:
Table

Variables

First Delphi Stage Clarity Relevance

\begin{tabular}{lll}
\hline Questions pertaining to knowledge & $\mathrm{CVI} *$ & $\mathrm{CVI}$
\end{tabular}
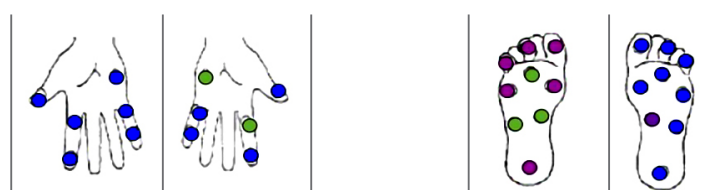

Legenda: Canela/filamento lilás (2g): Sente $\checkmark$ Não sente $X$ ou Monofilamentos: seguir cores Garra móvel: $\mathbf{M}$ Garra rígida: R Reabsorção: "IIIJ/! Ferida: $\square$

Based on this information, what is this individual's degree of disability?

[ ] degree 0 [ ] degree 1 [ ] degree 2

6. I. A. N., 28 years old, female, arrived at the hospital's dermatology clinic with a complaint of anhidrosis in the region of the nose, hands, and feet, confirmed during the inspection stage. During palpation of the nerve trunks, thickening of the median nerve of the right upper limb and tibial nerve of the right lower limb were observed. During strength examination, a normal degree of strength was verified for all movements (abduction of the fifth finger, abduction of the thumb and wrist extension, hallux extension, and ankle dorsiflexion). The sensitivity test presented the following monofilament color scheme:
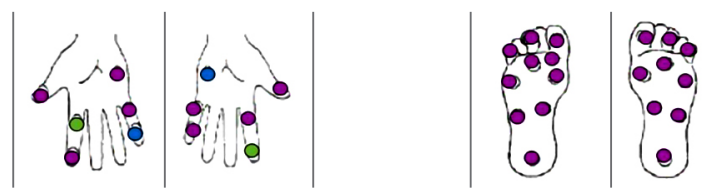

Legenda: Canela/filamento lilás (2g): Sente $\checkmark$ Não sente $X$ ou Monofilamentos: seguir cores Garra móvel: $\mathbf{M}$ Garra rígida: R Reabsorção: "IIIf/!, Ferida: $\square$

Based on this information, what is this individual's degree of disability?

[ ] degree 0 [ ] degree 1 [ ] degree 2

7. M. H. E., 45 years old, female, arrived at the hospital's dermatology clinic presenting three lesions with a hypochromic center and brownish edges measuring approximately $5 \mathrm{~cm}$ to $10 \mathrm{~cm}$. In the physical examination of the face, there were no changes in the nose, however, there was a decrease in the strength of ocular closure. During palpation of the nerve trunks, pain and thickening were identified in the median nerve of the right upper limb; and tibial and fibular of the left lower limb. During strength examination, there was a decreased degree of strength for the left upper limb (abduction of the fifth finger, abduction of the thumb, and of the wrist extension) and decreased for the left lower limb (extension of the hallux and dorsiflexion of the ankle). The sensitivity test presented the following monofilament color scheme:
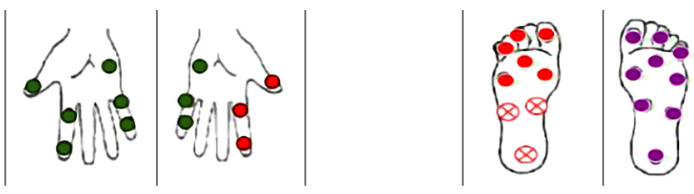

Legenda: Canela/filamento lilás (2g): Sente $\checkmark$ Não sente $X$ ou Monofilamentos: seguir cores

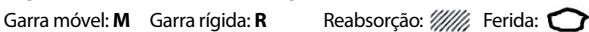

Based on this information, what is this individual's degree of disability?

[ ] grau 0 [ ] grau 1 [ ] grau 2 
Table 2 - Judges' assessment regarding the criteria of clarity and relevance of the questions related to attitudes, according to the Content Validity Index in the first Delphi stage ( $\mathrm{N}=13)$, João Pessoa, Paraíba, Brazil, 2019

\begin{tabular}{lc}
\hline Variables & $\begin{array}{c}\text { Second Delphi } \\
\text { Stage } \\
\text { Clarity }\end{array}$ \\
\hline Attitudelevance \\
\hline
\end{tabular}

8. Performing the simplified neurological evaluation and determining leprosy patients' degree of physical disability is part of my assignment.

$0.38 \quad 1$

[ ] Agree [ ] Disagree [ ] l don't know/don't have an opinion

9. Performing a simplified neurological evaluation of patients with leprosy is important to support health care planning.

[ ] Important [ ] Not Important [ ] I don't know/don't have an opinion

10. How do you assess your ability to carry out the leprosy patient's anamnesis through simplified neurological evalutation?

[ ] I'm qualified [ ] I'm not qualified [ ] I don't know/don't have an opinion

11. How do you assess your ability to perform nerve palpation on a leprosy patient through simplified neurological evaluation?

$0.76 \quad 1$

[ ] I'm qualified [ ] I'm not qualified [ ] I don't know/don't have an opinion

12. How do you assess your ability to assess leprosy patients' sensitivity through simplified neurological evaluation?

0.84

[ ] I'm qualified [ ] I'm not qualified [ ] I don't know/don't have an opinion

13. How do you assess your ability to assess leprosy patients' muscle strength through simplified neurological evaluation?

[ ] I'm qualified [ ] I'm not qualified [ ] I don't know/don't have an opinion

14. Performing the simplified neurological evaluation of patients with leprosy in the diagnosis, every three months, at discharge for cure and/or whenever there are complaints is:

[ ] Adequate [ ] Inadequate [ ] I don't know/ don't have an opinion

15. Failure to perform the simplified neurological evaluation, at least twice, causes disabilities/ injuries to users with leprosy.

[ ] Agree [ ] Disagree [ ] / don't know/don't have an opinion

Note: ${ }^{*} \mathrm{CVI}=$ Content Validity Index.

Chart 1 shows the items that needed to be modified/reformulated, as well as the requirements related to the problem and suggestions for improvement and/or reformulation.

It is worth mentioning that there were disagreements between the judges regarding the negative questions in the instrument, however, by arguing that the inclusion of this affirmative format is a strategy used in the development of scales and that the CVI remained above the proposed, such suggestions were not accepted.
After the second Delphi stage of instrument evaluation, all items obtained a CVI above the recommended agreement rate (0.90). In this step, in addition to the CVI, the Kappa Index was also calculated between the two assessments performed by each judge, presenting an excellent/almost perfect classification, that is, between 0.80 and 1.00 for both constructs (Table 3 ).

Chart 1 - Judges' suggestions regarding the items considered for modification ( $\mathrm{N}=13)$, João Pessoa, Paraíba, Brazil, 2019

\begin{tabular}{|c|c|c|}
\hline Item & $\begin{array}{l}\text { Assessed } \\
\text { requirements } \\
\text { that needed } \\
\text { changing }\end{array}$ & Judges' suggestions \\
\hline 1 & Clarity & $\begin{array}{l}\text { Removing "have you heard" and replace } \\
\text { it by "for leprosy provided by the Ministry } \\
\text { of Health" }\end{array}$ \\
\hline 2.1-2.12 & Clarity & $\begin{array}{l}\text { Insert the term "Simplified Neurological } \\
\text { Evaluation" }\end{array}$ \\
\hline 2.2 & Clarity & Add "and perform the reaction diagnosis" \\
\hline 2.3 & Clarity & $\begin{array}{l}\text { Add at the end of the item "proposed by } \\
\text { the World Health Organization" }\end{array}$ \\
\hline 2.4 & Clarity & $\begin{array}{l}\text { Replace "caudal" with "podal" and insert } \\
\text { "head, upper and lower limbs" }\end{array}$ \\
\hline 2.6 & Clarity & Rephrase the affirmation \\
\hline 2.7 & Clarity & Add "no flavor" \\
\hline 2.11 & Clarity & $\begin{array}{l}\text { Modify "strength of closing the eyes" by } \\
\text { "occlusion of the eyelids with and without } \\
\text { force" }\end{array}$ \\
\hline 2.12 & Clarity & $\begin{array}{l}\text { Replace numerical degrees with nominal } \\
\text { terms }\end{array}$ \\
\hline 3.1 & Clarity & Rephrase the affirmation \\
\hline $3.2-3.8$ & Clarity & $\begin{array}{l}\text { Insert the term "Degree of Disability } \\
\text { proposed by the World Health } \\
\text { Organization" }\end{array}$ \\
\hline 3.2 & Clarity & Modify "accomplished" by "determined" \\
\hline 3.3 & Clarity & $\begin{array}{l}\text { Modify "sites" by "segments" and "prevail" } \\
\text { for "being noted" }\end{array}$ \\
\hline 3.4 & Clarity & Include "only" \\
\hline 3.5 & Clarity & Replace "2 g (lilac)" with "0.05 g (green)" \\
\hline 3.6 & Clarity & $\begin{array}{l}\text { Replace "signs are present in the eyes" } \\
\text { with "eyes may present signs" }\end{array}$ \\
\hline 3.7 & Clarity & Include "at least" \\
\hline 3.8 & Clarity & Add "in one or both hands" \\
\hline $4-7$ & Clarity & $\begin{array}{l}\text { Review affirmations, add "patient", } \\
\text { "diagnosed with leprosy", right and left } \\
\text { sides in the images, the answer option "I } \\
\text { don't know" and the phrase "the sensitivity } \\
\text { test is shown in the figure below } \\
\text { according to the color scheme of the } \\
\text { monofilaments at each assessed point:" }\end{array}$ \\
\hline $\begin{array}{c}8,9 \\
14-15\end{array}$ & Clarity & Replace "user" with "patient" \\
\hline 8 & Clarity & Add "from the World Health Organization" \\
\hline 11 & Clarity & Replace "nervous" with "peripheral nerves" \\
\hline 12 & Clarity & Add "eyes, hands, and feet" \\
\hline 14 & Clarity & Add "disease-related" \\
\hline 15 & Clarity & Rephrase affirmation \\
\hline
\end{tabular}


Table 3 - Judges' assessment regarding the clarity and relevance criteria of each instrument item, according to the Content Validity Index in the second Delphi stage and Kappa Index $(\mathrm{n}=11)$, João Pessoa, Paraíba, Brazil, 2019

\begin{tabular}{llcc}
\hline Requirement & Construct & $\begin{array}{c}\text { CVI } \\
\text { Second Delphi stage }\end{array}$ & $\begin{array}{c}\text { Kappa } \\
\text { Index }\end{array}$ \\
\hline $\begin{array}{l}\text { Relevance } \\
\text { Clarity }\end{array}$ & Knowledge & 1.00 & 1.00 \\
$\begin{array}{l}\text { Relevance } \\
\text { Clarity }\end{array}$ & Attitudes & 1.00 & \\
\hline
\end{tabular}

Note: ${ }^{*} \mathrm{CV} I=$ Content Validity Index.

\section{DISCUSSION}

Considered fundamental for the development and adaptation of measurement instruments, content validation represents the initial procedure of association between abstract concepts and measurable indicators, referring to the degree to which the content of an instrument adequately reflects the construct that is being measured ${ }^{(15-16)}$.

During the process of validating an instrument, specialists in the area of interest are selected to make judgment of the items as to clarity and relevance ${ }^{(17)}$; and, in the case of this study, the judges'vast experience, both in leprosy clinical management and in the conduct of studies, resulting in publications in national and international journals, contributed to ensuring a safe validation of the instrument.

In the first Delphi assessment stage, the exclusion of item 2.8 was requested, which discussed the observation of anhidrosis by finding dry area "islets" from the patient's skin. This item was excluded considering the fact that, despite the change in sweat function being a characteristic clinical manifestation of leprosy, it is not specifically addressed in the SNE form ${ }^{(3)}$ and could confuse respondents.

With regard to the reformulations, item 2.6 of the "knowledge" construct was restructured, since the assessment of hand and foot sensitivity must be carried out primarily using the SemmesWeinstein monofilaments; and, only in the absence of these, can the pressure of the weight of the tip of a ballpoint pen be used.

The sensitivity assessment test is performed with six nylon $(0.05$ $\mathrm{g}, 0.2 \mathrm{~g}, 2 \mathrm{~g}, 4 \mathrm{~g}, 10 \mathrm{~g}$, and $300 \mathrm{~g}$ ) baseline tactile Semmes-Weinstein monofilaments at specific points on the hands and feet, and its use is recommended due to its low cost, being easy to handle, and good reliability for early detection of nervous function disorders ${ }^{(18)}$.

A comparative study between the skin sensitivity test with the monofilaments and the hand and feet nerve conduction examination concluded that there is a correlation between the neurophysiological findings and the clinical criteria obtained with the monofilaments, pointing out their efficiency in the detection and monitoring of neural changes ${ }^{(19)}$.

Still within the "knowledge" construct, item 3.1 was reformulated to clarify that the DPD proposed by the WHO assesses the existence of loss of protective sensitivity and/or changes in muscle strength and/or visible deformity and/or blindness as a result of neural injury.

According to the signs and symptoms presented in the eyes, hands and feet, the DPD can vary from 0 to 2 , being classified as 0 when the individual does not present changes in these body segments; 1 when there is a decrease and/or loss of muscle strength and sensitivity; and 2, in the presence of visible deformities due to leprosy ${ }^{(3)}$.
The DPD evaluation is used to compose operational indicators of the Ministry of Health that monitor the progress of leprosy elimination as a public health problem, constituting an important tool to determine the early diagnosis, the success of activities that aim to interrupt the disease transmission chain and the risk of developing disabilities ${ }^{(3)}$.

In the "attitude" construct, only item 15 was reformulated, given that it mistakenly stated that failure to perform SNE could cause disabilities for patients, when in fact the neural monitoring performed through SNE can prevent the onset of deficiencies/injuries.

It is recommended that this monitoring be performed at the beginning of therapy, every three months during treatment in the absence of complaints, whenever there are complaints related to the disease, in the control of patients using corticosteroids, in reaction states and neuritis, at discharge of treatment and in the postoperative period of neural decompression ${ }^{(3)}$.

In addition, the replacement of some terms within the instrument was requested, as in items 2.4, in which the term "caudal" was changed to "podal" in line with the last published guideline ${ }^{(3)}$; 2.12 , in which the numerical graduation was changed to nominal, as the nominal terms are of greater domain and use by doctors and nurses in their practice; and eight, nine, 14, and 15, in which the term "user" was replaced by "patient", due to its little use in the Brazilian Portuguese language.

With regard to the clinical cases included in the instrument, to avoid uncertainties regarding the side of the body corresponding to each figure, the letters " $D$ " (for right) and " $E$ " (for left) were inserted above each figure, making the exposed hypothetical situation clearer.

It is worth highlighting the importance of including clinical cases in an instrument that assesses the level of knowledge of professionals about a disease, given the capacity of these cases to assist the professional in the development of clinical reasoning, which is fundamental for diagnostic and therapeutic decision-making ${ }^{(20)}$.

The identification of characteristic signs and symptoms of leprosy allows professionals to distinguish their clinical forms namely: undetermined, tuberculoid, dimorphic, and vichorvian - , contributing to the effectiveness of early diagnosis and appropriate treatment of patients, strategies that are essential to prevent the evolution of the disease ${ }^{(21)}$.

In view of the above, considering that the content and format of most items of the instrument were modified/reformulated through the contributions of experts, which allowed for reflection and deepening on the theme, the importance of carrying out studies of this nature is highlighted to create instruments that favor the implementation of improvements in the quality of patient care.

\section{Study limitations}

As a limitation, it is worth noting: the reduced number of judges who agreed to participate, when compared to the number of electronic invitations sent; and the delay in returning the test by some of them, hindering the speed of validation.

\section{Contributions to the field of nursing, health, or public policy}

The contribution of this study consists of making available an evaluation instrument on the knowledge and attitudes of PC 
professionals in light of the disabilities generated by leprosy. It will allow managers to identify gaps in the teaching-learning process of these professionals, subsidizing training planning, which contributes to improving the care provided to individuals with leprosy.

\section{CONCLUSION}

In general, the results, that is, CVIs above the recommended agreement rate (>0.90) and Kappa Index classified as excellent/ almost perfect $(K=1.00)$, indicate that the "Knowledge and Attitudes on Assessing Degrees of Physical Disability in Leprosy" instrument has an excellent content validity, and it can be inferred it is compatible with what it sets out to measure.

In this way, the instrument will allow measuring the scores obtained by professionals inserted in the reality of PC, with regard to the level of knowledge and attitudes that they have on the theme, prior to carrying out educational interventions. Thus, educational strategies can be directed to the greatest deficits found, since it is essential to guide clinical practice to have adequate knowledge and attitudes and in line with what is recommended by the Ministry of Health, being responsible for the comprehensive care of patients.

\section{REFERENCES}

1. Ministério da Saúde (BR). Secretaria de Vigilância em Saúde. Departamento de Vigilância das Doenças Transmissíveis. Boletim Epidemiológico: Caracterização da situação epidemiológica da hanseníase e diferenças por sexo, Brasil, 2012-2016. Brasília: Ministério da Saúde, 2018.

2. World Health Organization (WHO). Global leprosy update, 2017: reducing the disease burden due to leprosy. Weekly Epidemiol Rec[Internet] 2018 [cited 2020 Feb 27];35(93):445-56. Available from: https://apps.who.int/iris/bitstream/handle/10665/274290/WER9335-445-456. pdf?sequence $=1$ \&isAllowed $=y$

3. Ministério da Saúde (BR). Secretaria de Vigilância em Saúde. Departamento de Vigilância das Doenças Transmissíveis. Guia prático sobre a hanseníase. Brasília: Ministério da Saúde, 2017.

4. Carneiro DF, Silva MMB, Pinheiro M, Palmeira IP, Matos EVM, Ferreira AMR. Therapeutic itineraries in search of diagnosis and treatment of leprosy Rev Baiana Enferm. 2017;31(2):e17541. https://doi.org/10.18471/rbe.v31i2.17541

5. Souza ALA, Feliciano KVO, Mendes MFM. Visão de profissionais da Estratégia Saúde da Família sobre os efeitos do treinamento de hanseníase. Rev Esc Enferm USP. 2015;49(4):610-8. https://doi.org/10.1590/S0080-623420150000400011

6. Girão Neta OA, Arruda GMMS, Carvalho MMB, Gadelha RRM. Health professionals' and managers' perception of leprosy care within the family health strategy. Rev Bras Promoç Saúde. 2017;30(2):239-48. https://doi.org/10.5020/18061230.2017.p239

7. Santana EMF, Brito KKG, Antas EMV, Nogueira JA, Ledebal ODCP, Silva MA, et al. Factors associated with the development of physical disabilities in Hansen's disease. Rev Inst Med Trop Sao Paulo. 2018;60:e27. https://doi.org/10.1590/s1678-9946201860027

8. Raymundo VP. Construção e validação de instrumentos: um desafio para a psicolinguística. Letras Hoje. [Internet] 2009 [cited 2020 Feb 27];44(3):86-93. Available from: http://revistaseletronicas.pucrs.br/ojs/index.php/\%EE\%80\%80fale\%EE\%80\%81/article/viewFile/5768/4188

9. Dalmoro M, Vieira KM. Dilemas na construção de escalas Tipo Likert: o número de itens e a disposição influenciam nos resultados? Rev Gestão Organ. 2013;6(ed. Esp.). https://doi.org/10.22277/rgo.v6i3.1386

10. Andrade SSC, Zaccara AAL, Leite KMS, Brito KKG, Soares MJGO, Costa MML, et al. Knowledge, attitude and practice of condom use by women of an impoverished urban area. Rev Esc Enferm USP. 2015;49(3):364-72. https://doi.org/10.1590/S0080-623420150000300002

11. Fehring RJ. The Fehring model. In: Carrol-Johnson RM, Paquete M. Classification of nursing diagnoses: proceeding of the tenth conference. Philadelphia, EUA: Lippincott Company; 1994. p. 55-62.

12. Revorêdo LS, Maia RS, Torres GV, Maia EMC. O uso da técnica delphi em saúde: uma revisão integrativa de estudos brasileiros. Arq Ciênc Saúde. 2015;22(2):16-21 https://doi.org/10.17696/2318-3691.22.2.2015.136

13. Coluci MZO, Alexandre NMC, Milani D. Construção de instrumentos de medida na área da saúde. Ciênc Saúde Colet. 2015;20(3):925-36. https:// doi.org/1590/1413-81232015203.04332013

14. Medeiros RKS, Ferreira Jr MA, Pinto DPSR, Vitor AF, Santos VEP, Barrichello E. Modelo de validação de conteúdo de Pasquali nas pesquisas em Enfermagem. Rev Enf Ref. 2015;4:127-35. https://doi.org/10.12707/RIV14009

15. Souza AC, Alexandre NMC, Guirardello EB. Psychometric properties in instruments evaluation of reliability and validity. Epidemiol Serv Saúde. 2017;26(3). https://doi.org/10.5123/S1679-49742017000300022

16. Guanilo-Echevarria ME, Gonçalves N, Romanoski PJ. Psychometric properties of measurement instruments: conceptual basis and evaluation methods - part II. Texto Contexto Enferm. 2019;28:e20170311. https://doi.org/10.1590/1980-265X-tce-2017-0311

17. Pasquali L. Validade dos testes. Rev Examen [Internet] 2017 [cited 2020 Feb 27];1(1):14-48. Available from: https://examen.emnuvens.com.br/ rev/article/view/19/17

18. Silva CCR, Souza NSS, Souza TF. Monofilamento: conhecimento sobre sua utilização. Rev Estima. 2017;15(2):74-81. https://doi.org/10.5327/ Z1806-3144201700020003

19. Quaggio CMP, Soares FAMS, Lima MAXC. Uso dos Monofilamentos de Semmes Weinstein nos últimos cinco anos: revisão bibliográfica. Salusvita [Internet]. 2016 [cited 2020 Feb 27];35(1):129-42. Available from: https://pdfs.semanticscholar.org/533c/00ae4f896d06c3b70eaff9527ff8ea65f3 6c.pdf 
20. Fernandes RAF, Ibiapina CC, Timóteo APP, Malloy-Diniz LF. Dinâmica de desenvolvimento do raciocínio clínico e da competência diagnóstica na formação médica - sistemas 1 e 2 de raciocínio clínico. Rev Med Minas Gerais. 2016;26(Supl 6):15-8. https://doi. org/10.5935/2238-3182.20160052

21. Moura LMA. Estratégias utilizadas pelos serviços de saúde na detecção precoce da hanseníase: uma revisão integrativa. Rev Saúde Foco [Internet]. 2015 [cited 2020 Feb 27];2(1):130-50. Available from: http://www4.fsanet.com.br/revista/index.php/saudeemfoco/article/ view/524/850 